\title{
Overexpression of ID1 promotes tumor progression in penile squamous cell carcinoma
}

\author{
XIHENG HU $^{1}$, MINGFENG CHEN ${ }^{1}$, YANGLE LI $^{1}$, YIN WANG ${ }^{2}$, SAILAN WEN $^{2}$ and FU JUN ${ }^{3}$ \\ Departments of ${ }^{1}$ Urology, ${ }^{2}$ Pathology and ${ }^{3}$ Oncology, Xiangya Hospital, Central South University, \\ Changsha, Human 410008, P.R. China
}

Received July 5, 2018; Accepted November 30, 2018

DOI: $10.3892 /$ or.2018.6912

\begin{abstract}
Penile squamous cell carcinoma (PSCC) occurs more frequently in developing countries, and is commonly diagnosed at an advanced stage with an unfavorable prognosis. At present, few biomarkers for PSCC have been identified and used in clinical practice. Aberrant expression of inhibitor of DNA binding 1 (ID1) has been suggested as a potential regulator of tumor progression in various types cancer. Herein, we evaluated ID1 expression in PSCC and analyzed its association with the clinicopathological parameters of PSCC. Our findings indicated that ID1 overexpression is associated with histological subtype and lymph node metastasis. Kaplan-Meier survival analysis showed that the overexpression of ID1 is associated with unfavorable cancer-specific survival. In Cox proportional hazard models, ID1 overexpression was found to be an independent predictor of cancer-specific survival. Furthermore, we investigated the function of ID1 in PSCC using a PSCC cell line Penl1. Silencing of ID1 expression retarded cell growth, inhibited clonogenesis, and attenuated cell migration and invasion in Penl1 cells. ID1 may regulate key oncogenic and metastasis-related molecules, as depletion of ID1 expression affected the levels of p-AKT, p16, PTEN and cleaved caspase-3, and reduced MMP2/9 secretion in Penl1 cells. Nevertheless, the mRNA expression of p16 and PTEN increased following ID1 knockdown, suggesting that ID1 may repress p16 and PTEN expression in Penl1 cells. Therefore, overexpression of ID1 could serve as a potential prognostic biomarker for the clinical management of PSCC. Strategies targeting ID1-regulated signaling pathways may have therapeutic benefit in PSCC.
\end{abstract}

Correspondence to: Dr Fu Jun, Laboratory of Oncology Research, Department of Oncology, Xiangya Hospital, Central South University, 87 Xiangya Road, Changsha 410008, P.R. China E-mail: jf2017@csu.edu.cn

Key words: penile cancer, ID1, clinical outcome, prognosis, targeted therapy

\section{Introduction}

Penile cancer, a relatively rare cancer, arises from the squamous epithelium of the glans, coronal sulcus or inner preputial surface (1). Penile squamous cell carcinoma (PSCC) comprises the majority of cases of penile cancer (2). Currently, surgical operation is recommended as the major treatment for penile cancer. In addition to the surgical approach, brachytherapy, chemotherapy and targeted therapy have also been applied in the clinical management of penile cancer (3). Clinical outcomes of penile cancer are associated with tumor grade and stage, with the presence of inguinal nodal metastases being the most important prognostic factor for cancer-specific survival (4). Despite considerable progress in clinical treatment, the survival of the patients with PSCC has not improved during the previous 20 years (5).

Biomarkers are increasingly used in cancer diagnosis and clinical management. Improved understanding of the molecular/genetic mechanisms related to the development of penile cancer has allowed for the clinical use of novel biomarkers (6). Some molecular markers have already been studied in penile cancer, including Human papilloma virus (HPV), p53, p16, SCC antigen, Ki-67 and Wnt/ $\beta$-catenin (6-9). These markers are not predictive of tumor progression/metastasis. Inhibitor of DNA binding 1 (ID1) is a helix-loop-helix (HLH) protein overexpressed in several cancer types including prostate, breast and lung cancer $(10,11)$. ID1 exerts critical functions in the regulation of cell proliferation, differentiation and malignant transformation (12). Shuno et al showed that ID1 knockdown inhibits the metastatic potential of pancreatic cancer (13). Li et al demonstrated that ID1 promotes the tumorigenicity and metastasis of human esophageal cancer cells through activation of the PI3K/AKT signaling pathway (14). Overexpression of ID1 protein regulated angiogenesis in ovarian cancer tumors (15). ID1 was also found to regulate head and neck squamous cell carcinoma survival via the NF- $\mathrm{kB} /$ survivin and phosphoinositide 3-kinase/Akt signaling pathways (16). Recently, we showed that ID1 is a crucial factor regulating tumor initiation and malignant progression in glioma $(17,18)$. However, the role of ID1 in penile cancer warrants investigation. Herein, we sought to examine the expression of ID1 in PSCC and to determine its association with clinicopathological parameters. Our findings suggested that overexpression of ID1 is significantly correlated with lymph node metastasis in PSCC. 
Therefore, ID1 may be potentially useful as a novel biomarker or therapeutic target for PSCC.

\section{Materials and methods}

Patient cohort. The patients enrolled in this study $(\mathrm{n}=64$; median age, 56 years old, range, 28-87 years old) were diagnosed with PSCC and underwent penectomy (from February 2011 to November 2015) at Xiangya Hospital Central South University. Patients with known chemotherapy or brachytherapy before surgery were excluded from the study. Penile cancer tissues and matched adjacent non-cancerous penile tissues were also collected ( $n=7$; from March 2016 to June 2016) for western blot analysis. The research protocols were approved by the Institutional Research Ethics Committee of Xiangya Hospital and informed consent was acquired from all the patients (no. 201805847). The cases were reviewed by 2 genitourinary pathologists ( $\mathrm{YW}$ and $\mathrm{SW}$ ).

Representative paraffin-embedded archival blocks were used for sectioning ( $4-\mu \mathrm{m}$ thickness). All patients were prescribed a follow-up regimen based on the National Comprehensive Cancer Network guidelines (19), with physical examination every 3-6 months depending on nodal stage. Cancer and vital status were recorded by clinical follow-up at the Department of Urology, Xiangya Hospital (median follow-up, 22.5 months). TNM staging was assigned based on the American Join Committee on Cancer, 7th edition (19).

Reagents and cell line. Antibodies against ID1 (cat. no. ab66495) and $\beta$-actin (cat. no. ab8227) were purchased from Abcam (Cambridge, MA, USA); antibodies against p-AKT (cat. no. 4060), AKT (cat. no. 9272), p53 (cat. no. 2524), EGFR (cat. no. 4267), p16 (cat. no. 80772) and cleaved caspase-3 (cat. no. 9664) were all obtained from Cell Signaling Technology, Inc. (Beverly, MA, USA). Human PSCC cell line Penl1 was kindly provided by Professor Hui Han (Department of Urology, Cancer Hospital, Sun Yat-Sen University, Guangzhou, China) (20). Penl1 is routinely cultured in Dulbecco's modified Eagle's medium (DMEM) supplemented with $10 \%$ fetal bovine serum (FBS; HyClone Laboratories, South Logan, UT, USA), $4 \mathrm{mM}$ glutamine, $100 \mathrm{U} / \mathrm{ml}$ penicillin and $100 \mu \mathrm{g} / \mathrm{ml}$ streptomycin. Human epidermis keratinocyte cell line HaCat (resource no. 3111C0001CCC000373) was obtained from the Type Culture Collection of the Chinese Academy of Sciences (Shanghai, China). HaCat cells were grown in Minimum Essential Medium (MEM; HyClone Laboratories) supplemented with 15\% FBS. Lentiviral plasmids expressing scramble or shID1 shRNAs were purchased from GeneCopoeia, Inc. (Rockville, MD, USA). The sequences for the shRNAs and control shRNA used in the present study are listed as follows: ID1 shRNAs: sh-1, TTCCAACTTCGG ATTCCGAGT and sh-2, AAGTCTCTGGTGACTAGTAGG; scramble control, CCTAAGGTTAAGTCGCCCTCG. The packaging procedure for lentiviral shRNAs was conducted as previously described (20). After performing 2 consecutive virus infections, Penll cells were selected with puromycin $(1 \mu \mathrm{g} / \mathrm{ml})$ for 3 days.

Immunohistochemistry. Immunohistochemistry of tissue sections were performed as previously described (21).
Briefly, the sections were dewaxed in xylene, rehydrated with graded alcohols and subjected to heat-induced epitope retrieval. The sections were then incubated overnight at $4^{\circ} \mathrm{C}$ with a rabbit polyclonal anti-ID1 antibody (dilution 1:200), followed by incubation with a horseradish peroxidase conjugated goat anti-rabbit secondary antibody (dilution 1:200; cat. no. P044801-2; Dako, Glostrup, Denmark) for $30 \mathrm{~min}$ at room temperature. Immunochemical staining was visualized by reaction with 3,3-diaminobenzidine and hydrogen peroxide chromogen substrate (Dako). Slides were counterstained with hematoxylin and mounted with a coverslip. The negative controls were incubated with isotype rabbit IgG. ID1 expression was scored by 2 clinical pathologists (YW and SW). Immunostaining of ID1 was assessed using a scoring system as previously described (22). Staining positivity ( $\geq 30 \%)$ was regarded as overexpression.

HPV detection. HPV detection was conducted by SPF10 polymerase chain reaction and DEIA as previously described (23). Briefly, total genomic DNA was extracted from FFPE tissue material using Qiagen QIAamp DNA Micro kit (Qiagen, Inc., Valencia, CA, USA). Each DNA isolation run and PCR run contained HPV-positive and -negative controls. Specimens were tested for HPV DNA by PCR amplification/typing using the HPV SPF10 PCR DEIA assay (Labo Biomedical Products, Rijswijk, The Netherlands).

Clonogenic survival assay. Clonogenic survival assay was used to measure the tumorigenic potential of the Penl1 cells (24). Briefly, Penl1 cells $\left(5 \times 10^{2}\right)$ were plated in 6 -cm culture dishes, and cultured for 12 days, and the number of surviving colonies (defined as a colony with $>50$ cells) was stained with $0.5 \%$ crystal violet and counted with an Olympus CKX41 microscope (Olympus Corp., Tokyo, Japan) at x40 magnification.

Cell viability analysis. Cell viability was determined by Cell Counting Kit-8 assay (CCK-8; Dojindo Laboratories, Kumamoto, Japan) as previously described (25). Briefly, Penl1 cells were seeded $\left(2 \times 10^{3}\right.$ cells/well) into 96 -well plates. After different time-points (day 1, 2, 3, 4, 5 and 6) in the culture, $10 \mu \mathrm{l}$ of CCK-8 solution was added and incubation was carried out for $1 \mathrm{~h}$ at $37^{\circ} \mathrm{C}$. The optical density (OD) value (absorbance) was measured at $450 \mathrm{~nm}$ by Infinite F50 microplate reader (Tecan Group, Ltd., Männedorf, Switzerland).

Western blot analysis. Western blot analysis was conducted as previously described (26). Briefly, cells were lysed and quantified using Bicinchoninic Acid Protein (BCA) Assay kit (Beyotime Institute of Biotechnology, Shanghai, China). Protein lysates $(15 \mu \mathrm{g})$ were separated by $10 \%$ SDS-PAGE and transferred to polyvinylidene difluoride (PVDF) membranes (EMD Millipore, Billerica, MA, USA). Blots were blocked with 5\% non-fat dry milk in Tris-buffered saline buffer for $2 \mathrm{~h}$ at room temperature and then incubated with diluted antibodies (dilution 1:1,000) overnight at $4^{\circ} \mathrm{C}$, followed by incubation with horseradish peroxidase-conjugated secondary antibody (dilution 1:5,000; cat. no. ab7090; Abcam) for $1 \mathrm{~h}$ at room temperature. The blotting signal was visualized using an enhanced chemiluminescence detection reagent (ECL; Abcam). $\beta$-actin served as a loading control. 
Wound healing assay. Wound healing assay was used to evaluate the cell migration ability as previously described (27). Briefly, Penl1 cells $\left(5 \times 10^{5}\right)$ were grown in 6-well plates for $48 \mathrm{~h}$ until the cells achieved confluency. A sterile $200-\mu 1$ pipette tip was used to make a scratch wound in the center of the well. After $24 \mathrm{~h}$, the distance between the wound sides was measured with an Olympus CKX41 microscope (unit: $\mu \mathrm{m}$ ), respectively.

Transwell invasion assay. Cell invasion assays were performed using Transwell chamber with $8-\mu \mathrm{m}$ pores (Corning Inc., Corning, NY, USA) as previously described $(28,29)$. Briefly, Penl1 cells $\left(5 \times 10^{5}\right.$ cells/well) were seeded in Transwell inserts pre-coated with $50 \mu \mathrm{l}$ Matrigel. The plates were incubated for $36 \mathrm{~h}$ at $37^{\circ} \mathrm{C}$. The invaded cells on the bottom surface of the membrane were fixed using dehydrated alcohol, and stained by $0.2 \%$ crystal violet solution (Sigma-Aldrich; Thermo Fisher Scientific, Inc., Waltham, MA, USA). After being washed with deionized water, Penll cells were photographed with an Olympus BX43 light microscope (magnification, x100). The crystal violet in stained cells were eluted by $20 \%$ glacial acetic acid and were measured with a microplate reader (Tecan Schweiz AB) at $570 \mathrm{~nm}$.

ELISA assay for MMP2 and MMP9. Cell supernatant was centrifuged at $12,000 \mathrm{xg}$ for $15 \mathrm{~min}$ at $4^{\circ} \mathrm{C}$. MMP2 ELISA and MMP9 ELISA kits (Sigma-Aldrich; Merck KGaA, Darmstadt, Germany) were used to measure the levels of secreted MMP2 and MMP9 in Penl1 cells, respectively, according to the manufacturer's instructions and as previously described (30).

Real-time PCR. Real-time PCR was conducted as previously described (21). Briefly, total RNA was extracted from Penll cells using TRIzol reagent (Invitrogen; Thermo Fisher Scientific, Inc.) and further purified using the RNeasy Mini kit (Qiagen, Inc.). One microgram of total RNA was used to generate cDNA, which was then used for the quantitative PCR using SYBR-Green PCR expression assays (Invitrogen; Thermo Fisher Scientific, Inc.). Relative gene expression was determined based on the threshold cycles ( $\mathrm{Ct}$ values) of the genes (ID1, p16 and PTEN) and of the internal reference gene (ACTB). PCR primers for ID1, PTEN, $\beta$-actin and p16 genes are listed as follows: ID1: forward, CTGCTCTACGACATGAAC GG and reverse, GAAGGTCCCTGATGTAGTCGAT; P16: forward, ATGGAGCCTTCGGCTGACT and reverse, GTA ACTATTCGGTGCGTTGGG; PTEN: forward, TGGATT CGACTTAGACTTGACCT and reverse, GGTGGGTTATGG TCTTCAAAAGG; $\beta$-actin: forward, CATGTACGTTGCTAT CCAGGC and reverse, CTCCTTAATGTCACGCACGAT.

Caspase-3 activity assay. Apoptosis of NPC cells after exposure to irradiation was detected using Caspase-3 Colorimetric Assay kit (Abcam) based on the cleavage of Asp-Glu-Val-Asp (DEVD)-pNA. Briefly, NPC cells $\left(5 \times 10^{5}\right.$ cells) were lysed on ice for $10 \mathrm{~min}$ and centrifuged at 10,000 x g for $1 \mathrm{~min}$. Enzyme reactions were carried out on the resulting supernatants in 96-well flat-bottom microplates, using $50 \mu \mathrm{l}$ of cell lysate (100-200 $\mu \mathrm{g}$ of total protein) for each reaction mixture. The results are expressed as specific activities (UI/mg protein) of caspase-3.
Statistical analysis. The statistical software package SPSS 19.0 (IBM Corp., Armonk, NY, USA) was used in the present study. Descriptive statistics was used to summarize the clinicopathological features. Survival analysis was performed using the Kaplan-Meier method to determine the overall cancer-specific survival. The log-rank test was used to compare the survival curves. Significance between 2 groups was performed using the Student's t-test. Significance between $>2$ groups was evaluated by one way analysis of variance (ANOVA) followed by a Newman-Keuls post hoc test. Two-sided P-values $<0.05$ were considered to indicate a statistically significant result.

\section{Results}

ID1 is differentially expressed in non-cancerous penile tissues and PSCC tissues. ID1 expression in PSCC tissues $(\mathrm{n}=64)$ was analyzed by immunohistochemistry. In non-cancerous penile tissues, ID1 immunostaining was low or absent and confined mostly in the basal cells of the epithelium (Fig. 1A). ID1 exhibited differential immunostaining in the PSCC samples (case 1 and 2, ID1 overexpression; case 3 and 4, ID1 low expression). Overall, 20 (31.3\%) cases showed ID1 overexpression (staining positivity $\geq 30 \%$ ). ID1 exhibited mostly nuclear staining in PSCC tissues (Fig. 1A). Western blot analysis showed that ID1 was higher in cancer tissues than that in the adjacent non-cancerous tissues (Fig. 1B). The clinicopathological features of the study cohort are summarized in Table I. Overexpression of ID1 was associated with histological subtype $(\mathrm{P}=0.017)$ and lymph node metastasis $(\mathrm{P}=0.007)$. Kaplan-Meier survival analysis showed that overexpression of ID1 is associated with unfavorable cancer-specific survival (CSS) $(\mathrm{P}<0.001$; Fig. 2). In Cox proportional hazard models (Table II), ID1 overexpression was found to be an independent predictor of CSS [hazard ratio $(\mathrm{HR})=3.76 ; 95 \%$ confidence interval (CI) 1.33-10.65; $\mathrm{P}=0.013$ ]. Consistent with previous studies, we showed that the status of lymph node metastasis could also serve as an independent predictor of CSS (HR 3.42; 95\% CI, 1.16-10.08, $\mathrm{P}=0.025$ ). These results suggest that ID1 may play a critical role in the tumor progression of PSCC.

Knockdown of IDI expression suppresses cell growth and clonogenesis in Penll cells. Recently, Chen et al established a cell line (Penl1) derived from a lymph node metastasis of PSCC (20). Therefore, we sought to further investigate the oncogenic function of ID1 in PSCC using Penl1 as a cell model. We showed that ID1 exhibited higher expression in Penl1 than that in epidermis keratinocyte cells HaCat (Fig. 3A). Penl1 cells were transduced with non-targeting scramble (Scr) or 2 shRNAs targeting ID1 (sh-1 and sh-2). As shown in Fig. 3B, ID1 expression was significantly reduced in Penl1 cells transduced with the 2 shID1 lentiviruses, whereas it was not significantly affected by Scr shRNA. Consistently, the expression of ID1 mRNA was significantly decreased in the shID1 groups as compared to the Scr control ( $\mathrm{P}<0.05$; Fig. $3 \mathrm{C})$. We next examined the effect of ID1 expression on the cell growth of Penl1 cells by CCK-8 assay, and the results showed that shID1 transduced-Penl1 cells grew slower than those transduced with Scr shRNA $(\mathrm{P}<0.05$; Fig. 3D). Furthermore, colony formation of Penl1 cells in shID1 group was significantly decreased, as 

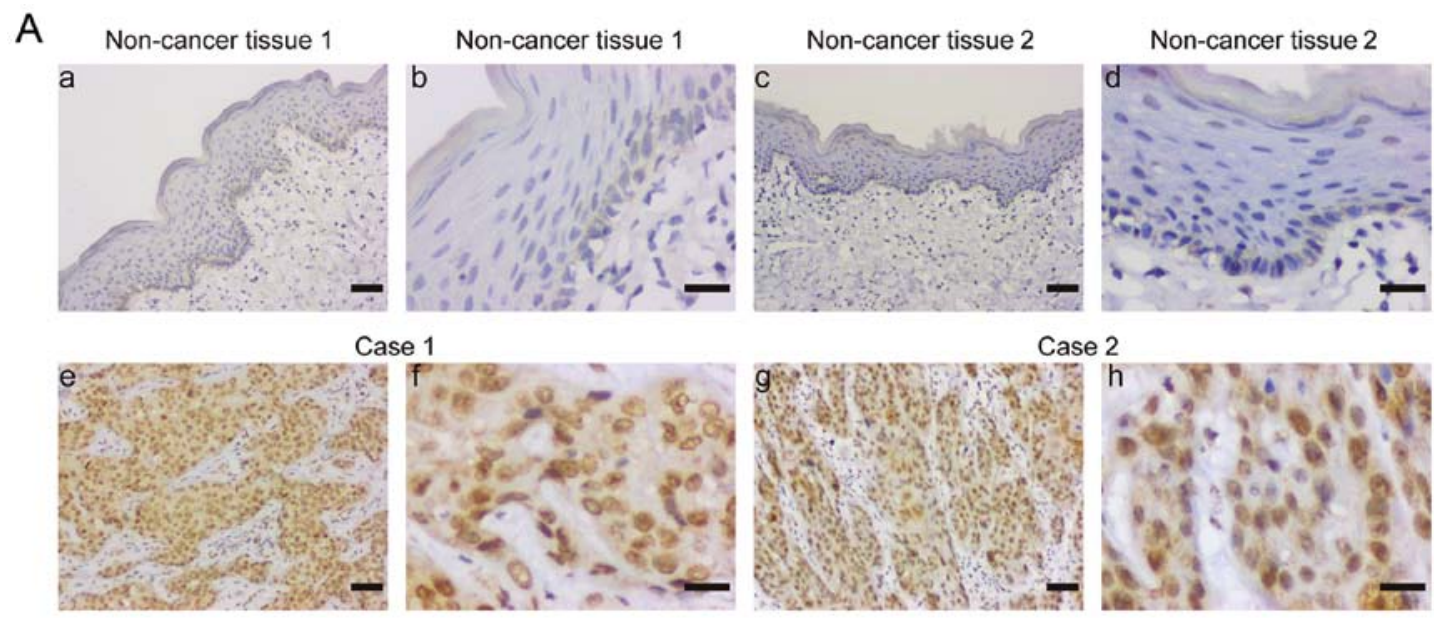

Case 2
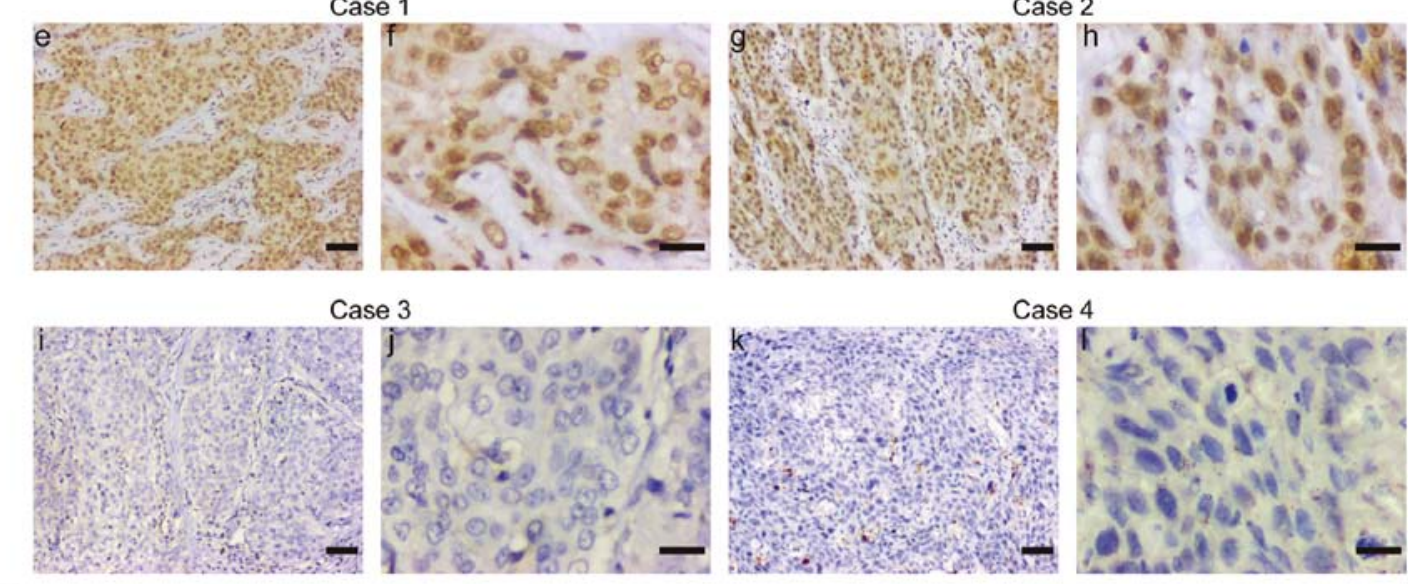

B
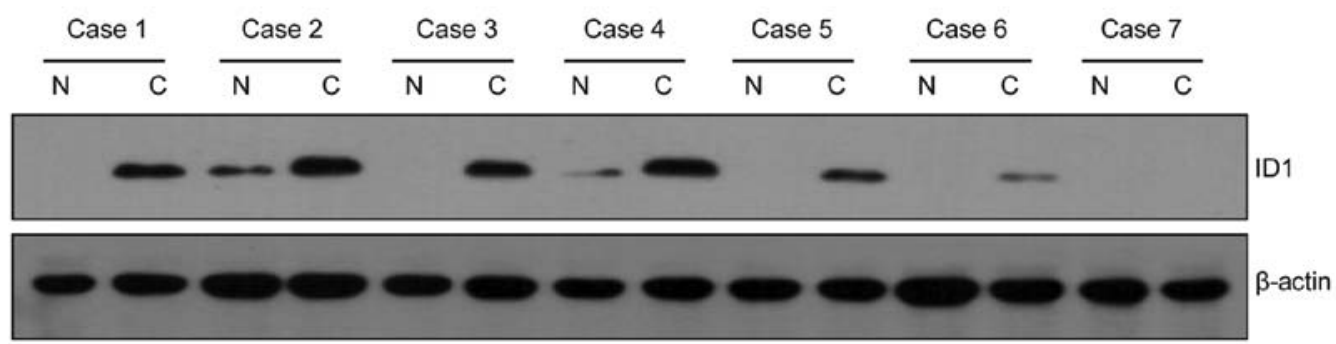

Figure 1. (A) Expression of ID1 in non-cancer penile tissues and PSCC. Scale bars: a, c, e, g, I and k, $100 \mu \mathrm{m}$; b, d, f, h, j and l, $20 \mu \mathrm{m}$. (B) Western blot analysis of the protein expression of ID1 in matched penile cancer tissues and adjacent non-cancerous tissues. $\beta$-actin served as a loading control. ID1, inhibitor of DNA binding 1; PSCC, penile squamous cell carcinoma; N, normal penile tissue, C, PSCC tissue.

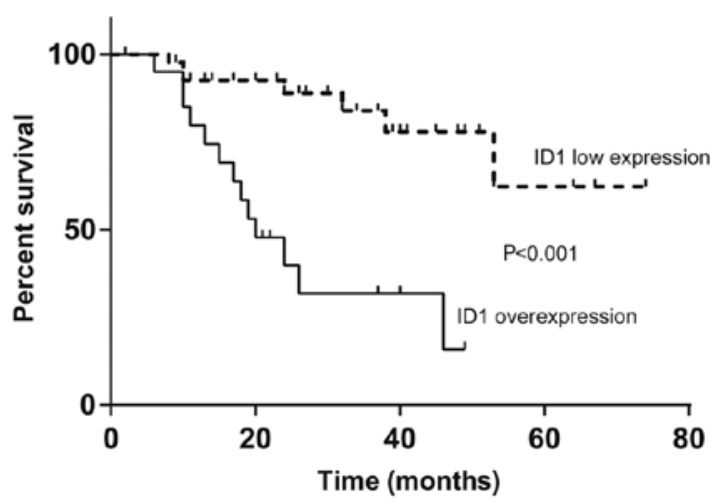

Figure 2. Overexpression of ID1 in PSCC is associated with unfavorable cancer-specific survival (CSS). The log-rank test was used to compare survival curves. ID1, inhibitor of DNA binding 1; PSCC, penile squamous cell carcinoma.

compared with the Scr group, $(\mathrm{P}<0.05$; Fig. 3E). Since both ID1shRNAs showed similar effect, ID1 sh-1 shRNA was used for the following experiments.

Depletion of IDI expression attenuates cell migration and invasion in Penll cells. The metastatic process involves cell scattering, motility, ECM degradation, migration and invasion through basement membranes (30). Since overexpression of ID1 is correlated with nodal disease and unfavorable overall survival, we proposed that ID1 may regulate the migration/invasion phenotypes in PSCC cells. To examine the effect of ID1 on cancer cell migration in vitro, we performed a wound-healing assay. We observed a significantly slower wound-healing rate in the cells expressing shID1 shRNA compared to the Scr control (Fig. 4A). Transwell invasion assay was also performed in order to examine the effects of ID1 on cell invasion. As shown in Fig. 4B, knockdown of ID1 expression attenuated the invasion of Penll cells, as compared with that noted in the Scr control. These results illustrated that ID1 may be an important regulator of cell migration and invasion in PSCC.

IDI regulates oncogenic and metastasis-related signaling pathways in Penll cells. Currently, little is known concerning the molecular mechanisms of the carcinogenesis of PSCC; HPV infection, mutations in p53 and H-Ras, and dysregulated pathways such as EGFR, PI3K/AKT/mTOR, p16, p53/p21, E-cadherin/WNT/ $\beta$-catenin and MMP2/9 have been identified as potential cancer-related genes/pathways involved in 
Table I. Demographic and clinicopathological characteristics of the study population associated with ID1 expression.

\begin{tabular}{|c|c|c|c|c|}
\hline Parameters & ID1 low expression n (\%) & ID1 overexpression n (\%) & $\chi^{2}$ & P-value \\
\hline Age (years) & & & 0.829 & 0.362 \\
\hline$<56$ & $23(52.3)$ & $8(40.0)$ & & \\
\hline$\geq 56$ & $21(47.7)$ & $12(60.0)$ & & \\
\hline pT stage & & & 0.524 & $0.469^{\mathrm{a}}$ \\
\hline $\mathrm{Ta} / \mathrm{T} 1$ & $5(11.4)$ & $5(25.0)$ & & \\
\hline $\mathrm{T} 2$ & $37(84.1)$ & $13(65.0)$ & & \\
\hline $\mathrm{T} 3 / \mathrm{T} 4$ & $2(4.5)$ & $2(10.0)$ & & \\
\hline Grade & & & 3.603 & $0.058^{\mathrm{a}}$ \\
\hline Low & $1(2.3)$ & $4(20.0)$ & & \\
\hline Intermediate & $6(13.6)$ & $3(15.0)$ & & \\
\hline High & $37(74.0)$ & $13(65.0)$ & & \\
\hline Histological subtype & & & 5.744 & $0.017^{\mathrm{a}}$ \\
\hline Usual & $24(54.5)$ & $17(85.0)$ & & \\
\hline Papillary & $1(2.3)$ & $0(0.0)$ & & \\
\hline Warty & $7(15.9)$ & $2(10.0)$ & & \\
\hline Verrucous & $12(27.3)$ & $1(5.0)$ & & \\
\hline Lymph node & & & 7.166 & 0.007 \\
\hline Negative & $31(70.5)$ & $7(35.0)$ & & \\
\hline Positive & $13(29.5)$ & $13(65.0)$ & & \\
\hline HPV status & & & 0.051 & 0.822 \\
\hline Negative & $32(72.7)$ & $14(70.0)$ & & \\
\hline Positive & $12(27.3)$ & $6(30.0)$ & & \\
\hline
\end{tabular}

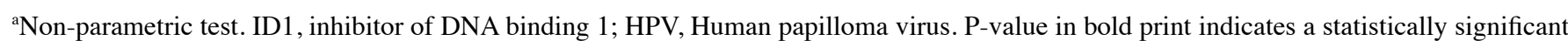
difference.

Table II. Cox proportional hazard model for death from disease by ID1 overexpression.

\begin{tabular}{llrl}
\hline & \multicolumn{1}{c}{ Univariate analysis } & & Multivariate analysis \\
\cline { 2 - 3 } Variables & HR $(95 \% \mathrm{CI})$ & P-value & HR (95\% CI) \\
\hline Age (<56 vs. $\geq 56$ years $)$ & $1.10(0.45-2.70)$ & 0.832 & \\
pT stage & $1.02(0.42-2.45)$ & 0.966 & \\
Grade & $0.78(0.42-1.42)$ & 0.414 & $3.42(1.16-10.08)$ \\
Histological subtype & $0.52(0.29-0.91)$ & 0.021 & 0.025 \\
Lymph node & $5.46(1.98-15.05)$ & 0.001 & $3.76(1.33-10.65)$ \\
HPV status & $0.53(0.18-1.58)$ & 0.251 & 0.013 \\
ID1 overexpression & $5.99(2.25-15.93)$ & $<0.001$ & 3 \\
\hline
\end{tabular}

HR, hazard ratio; CI, confidence interval; HPV, Human papilloma virus; ID1, inhibitor of DNA binding 1.

PSCC (6). As shown in Fig. 5A, knockdown of ID1 attenuated p-AKT and increased levels of tumor suppressor p16, PTEN and apoptotic molecule cleaved caspase-3, suggesting that ID1 may exert its oncogenic function via both activating AKT and downregulating p16 and PTEN expression. Real-time PCR analysis showed that mRNA expression of p16 and PTEN was increased in ID1-depleted Penl1 cells compared to that noted in the Scr control (Fig. 5B). As cleaved caspase-3 antibody cannot detect full-length caspase-3 expression, we next assessed the caspase- 3 activity in Penl1 cells. As shown in Fig. 5C, knockdown of ID1 considerably increased caspase-3 activity compared to the Scr control. Furthermore, ELISA assay revealed that depletion of ID1 reduced secretion of 2 invasion/metastasis-related molecules MMP2 and 
A

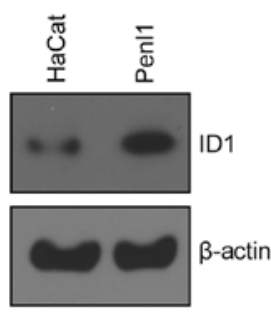

D

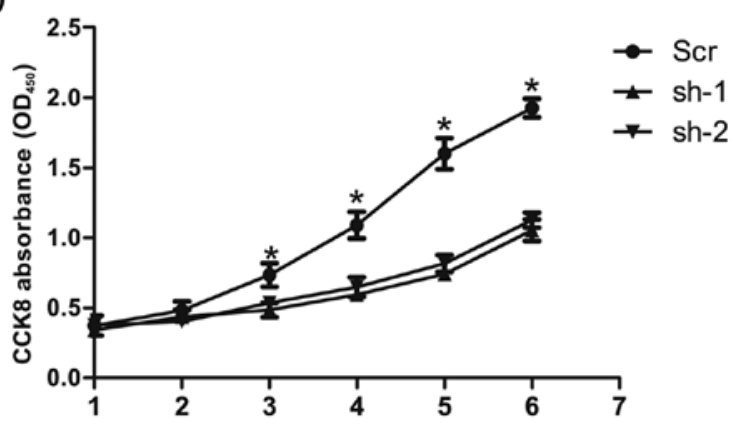

B

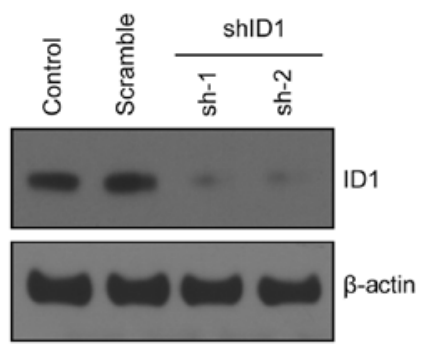

$\mathrm{E}$

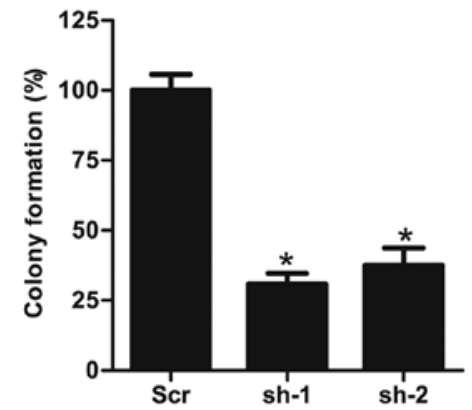

Figure 3. Knockdown of ID1 expression suppresses cell growth and clonogenesis in Penl1 cells. (A) Expression of ID1 in HaCat and Penl1 cells. $\beta$-actin served as a loading control. (B) ID1 expression was significantly reduced in Penl1 cells transduced with 2 shID1 lentiviruses (sh-1 and sh-2). $\beta$-actin served as a loading control. (C) Knockdown of ID1 reduced its mRNA expression in Penl1 cells. The expression of ID1 mRNA in Scr control was regarded as $100 \%$. "P $<0.05$, Scr vs. shID1. (D) Knockdown of ID1 expression attenuated cell growth of Penl cells. The CCK-8 absorbance was measured at $450 \mathrm{~nm}\left(\mathrm{OD}_{450}\right)$. ${ }^{*} \mathrm{P}<0.05$, Scr vs. sh-1 or sh-2. (E) Depletion of ID1 expression reduced clonogenesis of Penl1 cells. The colony formed in the scramble control (Scr) was regarded as $100 \%$. "P<0.05, Scr vs. sh-1 or sh-2. All experiments were performed 3 times, and data are presented as mean \pm SD values. ${ }^{*} \mathrm{P}<0.05$, Scr vs. sh-1 or sh-2. ID1, inhibitor of DNA binding 1 .

A
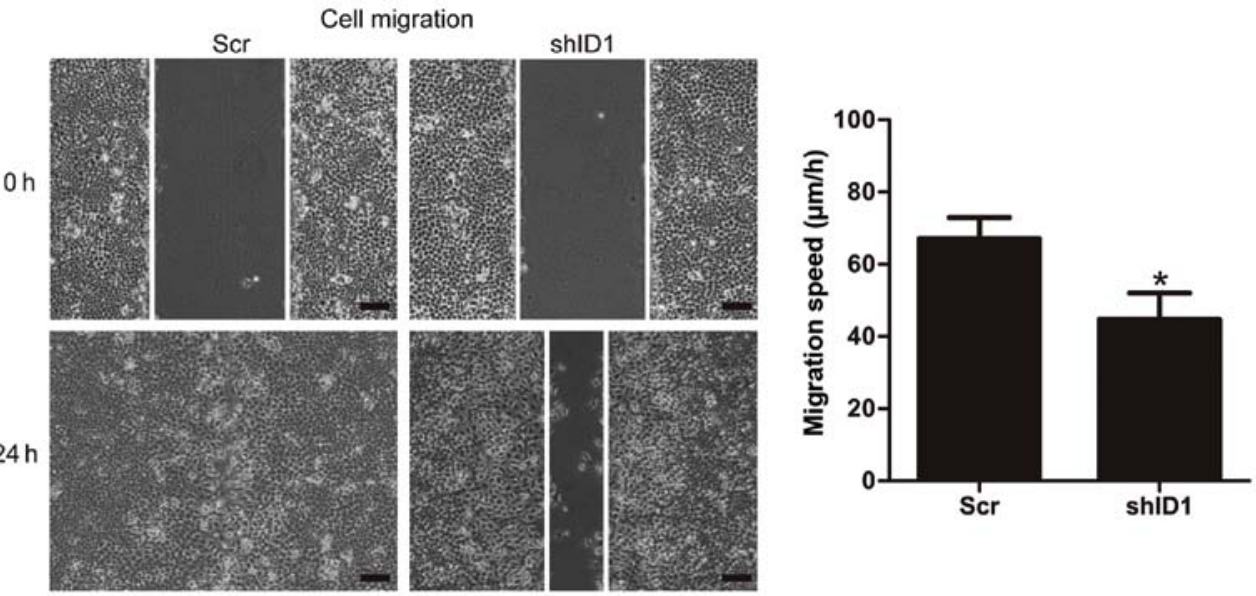

B
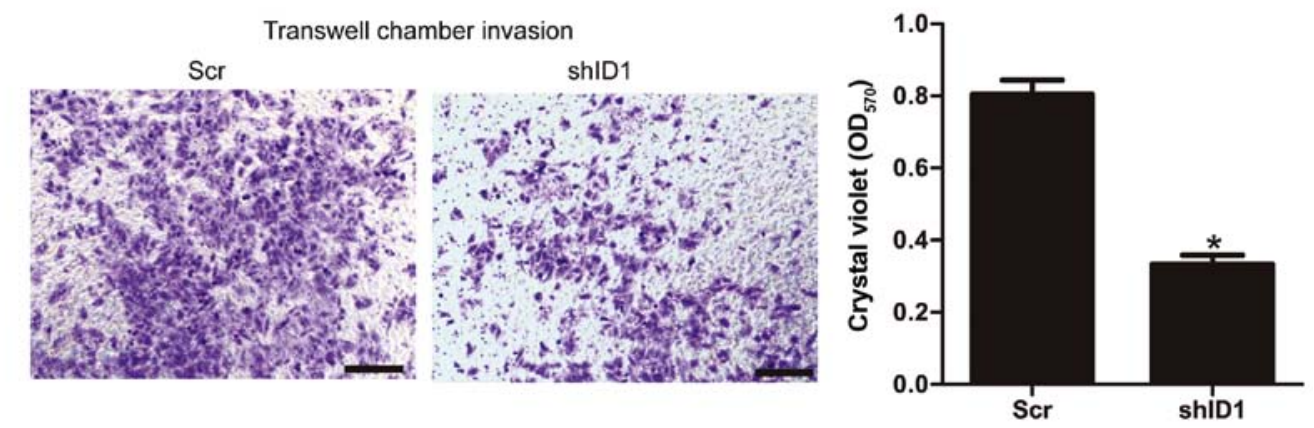

Figure 4. Depletion of ID1 expression inhibits cell migration and invasion in Penl1 cells. (A) Wound healing assay. The migration of the cells to the wound was measured at 0 and $24 \mathrm{~h}$ after scratch. The representative fields were photographed; the relative healing rates were quantified with measurements of the gap sizes after the culture. Three different areas in each assay were chosen to measure the distances of migrating cells to the origin of the wound. Scale bar, $100 \mu \mathrm{m}$. "P<0.05, Scr vs. shID1. (B) Transwell invasion assays with Penl1 cells were performed in scramble control and shID1 group. Crystal violet assay $\left(\mathrm{OD}_{570}\right)$ was conducted to evaluate cell migration and invasion capability. Scale bars, $100 \mu \mathrm{m}$. All experiments were performed 3 times, and data are presented as mean \pm SD values. " $\mathrm{P}<0.05$, Scr vs. shID1. ID1, inhibitor of DNA binding 1 . 
A

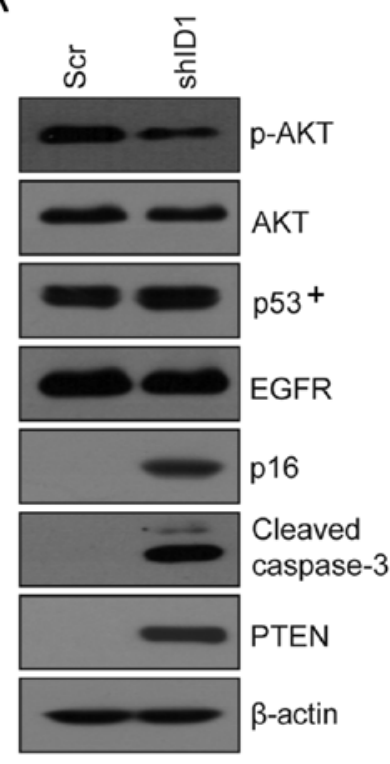

B

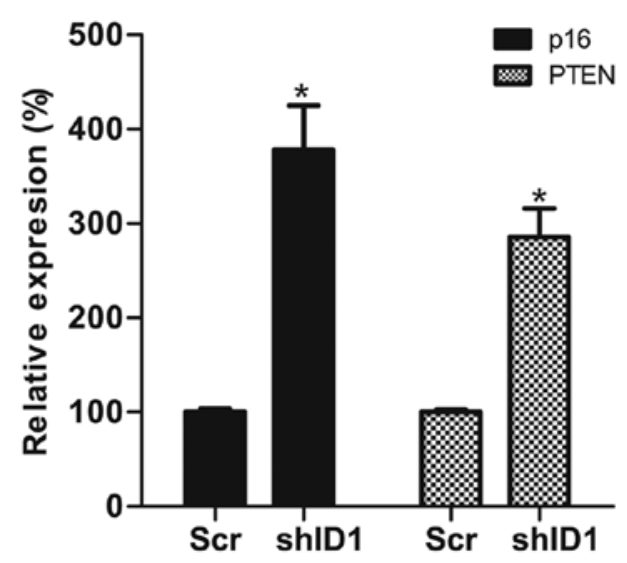

C

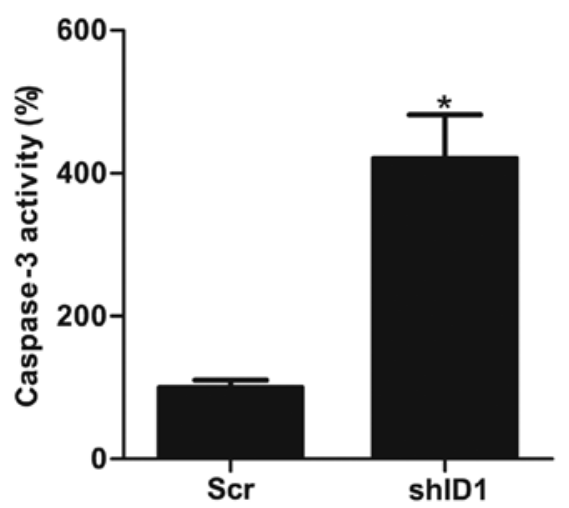

D

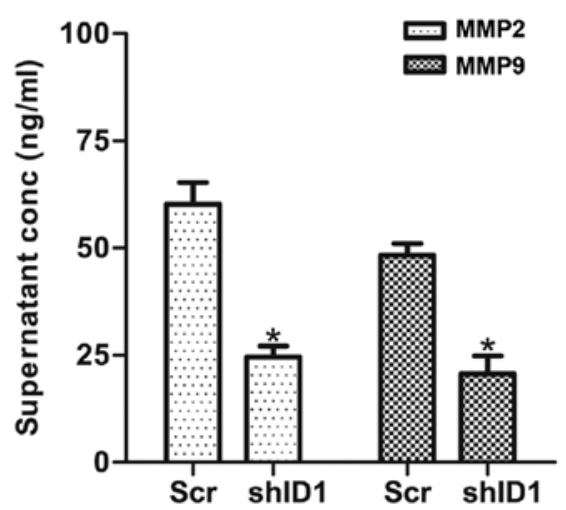

Figure 5. (A) Knockdown of ID1 affects p-AKT, p16, PTEN and cleaved caspase-3 expression in Penl1 cells. $\beta$-actin served as a loading control. (B) Depletion of ID1 expression increased p16 and PTEN mRNA expression in Penl1 cells. The expression of p16 or PTEN mRNA in Scr control was regarded as $100 \%$. ${ }^{*} \mathrm{P}<0.05$, Scr vs. shID1. (C) The effect of ID1 expression on caspase-3 activity. The caspase-3 activity in Scr control was regarded as $100 \%$. $\mathrm{P}<0.05$, Scr vs. shID1. (D) Knockdown of ID1 expression reduced MMP2/9 secretion in Penl1 cells. All experiments were performed 3 times, and data are presented as mean \pm SD values. ${ }^{*} \mathrm{P}<0.05$, Scr vs. shID1. ID1, inhibitor of DNA binding 1 .

MMP9, suggesting an involvement of the ID1-related pathway in regulating MMP2/9-mediated cell invasion and metastasis (Fig. 5D).

\section{Discussion}

The primary treatment for penile cancer is surgery (31). Although surgery alone can cure most of the patients with local disease, the clinical outcome for patients with advanced penile cancer still remains poor (31). Regional lymph node metastasis is the most important prognostic factor for predicting cancer-related survival (32). Prognostic biomarkers for the development of lymph node metastasis are being intensively investigated. Squamous cell carcinoma antigen (SCC), proliferating cell nuclear antigen (PCNA), cyclin D1, as well as other markers have been studied with limited clinical utility in penile cancer (6). However, none of them can predict lymph node status or exhibit prognostic value (6). Therefore, it is urgent to identify reliable biomarkers for the early diagnosis of nodal metastasis of penile squamous cell carcinoma (PSCC).

Several biomarkers have been under clinical investigation for their potential to predict lymph node metastasis. Lopes et al showed that p53 expression could serve as a new prognostic factor for lymph node metastasis in penile carcinoma (33). Ferrandiz-Pulido et al recently unveiled the mammalian target of rapamycin (mTOR) pathway in the development of lymph node metastasis (34). Poetsch et al indicated that loss of tumor-suppressor gene p16 is associated with aggressive behavior of penile carcinomas (35). In this study, we evaluated the ID1 expression in penile cancer and analyzed its association with oncologic outcomes. We showed that ID1 is differentially expressed in non-cancerous tissues and PSCC; ID1 overexpression could serve as an independent factor to predict cancer-specific survival. Several previous studies have indicated that the histological subtype of penile cancer is associated with more aggressive biological behavior and predicts patient survival (36-38). Consistently, we showed 
that ID1 expression is associated with the histological subtype of penile cancer. Therefore, ID1 may be a potential regulator of cancer progression in various histological subtypes. However, due to the limits of the small cohort $(n=64)$ enrolled in the present study, a larger PSCC cohort would be warranted in order to further elucidate the usefulness of ID1 as a biomarker for the prediction of prognosis in PSCC.

Tumor progression is mechanistically driven by alterations in the regulatory mechanisms of proliferation and migration/invasion. It has previously been shown that ID1 is overexpressed in $>20$ types of malignancies, and has been proposed as a key determinant of tumorigenesis and/or metastasis in a wide range of cancer tissues (39). ID1 overexpression is associated with proliferation/survival in cancer cells and is required for tumor initiation during metastatic colonization of the lung microenvironment (40). Consistently, we showed that ID1 overexpression is associated with nodal metastasis of penile cancer. However, the regulation and function of ID1 in the malignant progression of PSCC remains unclear. Recent genomic studies on penile cancer have not revealed any alterations (copy number change or amplification/mutation) in the ID1 gene (41-44). Aberrant epidermal growth factor receptor (EGFR) signaling is a major characteristic of many Human malignancies including penile cancer $(45,46)$. EGFR could serve as an adverse survival predictor in penile cancer $(45,46)$. In the present study, we showed that ID1 is associated with tumor progression and predicts unfavorable survival in penile cancer. As ID1 has been shown to be regulated by EGFR signaling and could mediate EGFR signaling to promote the growth and metastasis in lung and bladder cancer $(47,48)$, it is likely that ID1 may serve as a downstream mediator of EGFR signaling to promote tumor progression in penile cancer. Currently, there is no chemical inhibitor for ID1. Targeting the upstream regulatory pathway of ID1 may help to inhibit ID1 function and cure ID1-overexpressing penile cancer.

In a series of experiments in a PSCC cell line model, we showed that depletion ofID1 led to downregulation of proliferation, migration and/or invasion of Penl1 cells. Our findings also revealed that knockdown of ID1 attenuated p-AKT, increased tumor suppressor p16 and PTEN and reduced MMP2/9 levels. As activation of the AKT pathway and p16 status has already been demonstrated to be crucial for the tumor progression of PSCC, it would be reasonable to propose that the effects of ID1 may result from its function in regulating the balance of oncogene/tumor-suppressor genes, thus promoting the tumor progression of PSCC (49,50). ID1 could act as a transcriptional repressor to repress PTEN and p16 expression in cancer cells (51-53). Consistently, we observed that depletion of ID1 increased p16 and PTEN mRNA expression in Penl1 cells. Therefore, ID1 may repress PTEN (thus activate AKT) and p16 expression, and thus promote tumor progression in penile cancer. Nevertheless, we observed a significant induction of caspase-3 activity in ID1-depleted cells, suggesting that ID1 may regulate apoptosis-related pathways in penile cancer. Therefore, further technical analysis such as the apoptosis pathway, apoptosis detection and fluorescence activated cell sorting (FACS) would be needed in order to further elucidate the anti-apoptotic role of ID1 in penile cancer. Cumulatively, these results highlight the importance of ID1 in the regulation of cell proliferation and spread of PSCC, and suggest that ID1 expression may serve as a valuable prognostic biomarker and therapeutic target for patients with penile cancers.

\section{Acknowledgements}

Not applicable.

\section{Funding}

The present study was supported by the National Nature Science Foundation of China (no. 81672510).

\section{Availability of data and materials}

All data generated or analyzed during this study are included in this published article.

\section{Authors' contributions}

FJ designed the study and wrote the manuscript; $\mathrm{XH}$ and MC performed the experiments; XH and YL analyzed the experimental data; YW and SW conducted the IHC and scored the IHC staining results. All authors read and approved the manuscript and agree to be accountable for all aspects of the research in ensuring that the accuracy or integrity of any part of the work are appropriately investigated and resolved.

\section{Ethics approval and consent to participate}

The research protocols were approved by the Institutional Research Ethics Committee of Xiangya Hospital with informed consent acquired from all the patients.

\section{Patient consent for publication}

Not applicable.

\section{Competing interests}

The authors declare that they have no competing interests.

\section{References}

1. Paner GP, Stadler WM, Hansel DE, Montironi R, Lin DW and Amin MB: Updates in the eighth edition of the tumor-node-metastasis staging classification for urologic cancers. Eur Urol 73: 560-569, 2018.

2. Douglawi A and Masterson TA: Updates on the epidemiology and risk factors for penile cancer. Transl Androl Urol 6: 785-790, 2017.

3. Ottenhof SR, Leone AR, Horenblas S, Spiess PE and Vegt E: Advancements in staging and imaging for penile cancer. Curr Opin Urol 27: 612-620, 2017.

4. Barski D, Georgas E, Gerullis H and Ecke T: Metastatic penile carcinoma-an update on the current diagnosis and treatment options. Cent European J Urol 67: 126-132, 2014.

5. Ficarra V, Novara G, Boscolo-Berto R, Artibani W and Kattan MW: How accurate are present risk group assignment tools in penile cancer? World J Urol 27: 155-60, 2009.

6. Zargar-Shoshtari K, Sharma P and Spiess PE: Insight into novel biomarkers in penile cancer: Redefining the present and future treatment paradigm? Urol Oncol 36: 433-439, 2018. 
7. Stankiewicz E, Ng M, Cuzick J, Mesher D, Watkin N, Lam W Corbishley $\mathrm{C}$ and Berney DM: The prognostic value of Ki-67 expression in penile squamous cell carcinoma. J Clin Pathol 65 534-537, 2012

8. Mannweiler S, Sygulla S, Winter E and Regauer S: Two major pathways of penile carcinogenesis: HPV-induced penile cancers overexpress p16 ink4a, HPV-negative cancers associated with dermatoses express $\mathrm{p} 53$, but lack p16 $6^{\text {ink4a }}$ overexpression. J Am Acad Dermatol 69: 73-81, 2013.

9. Arya M, Thrasivoulou C, Henrique R, Millar M, Hamblin R, Davda R, Aare K, Masters JR, Thomson C, Muneer A, et al: Targets of Wnt/ $\beta$-catenin transcription in penile carcinoma PLoS One 10: e0124395, 2015.

10. Ling F, Kang B and Sun XH: Id proteins: Small molecules, mighty regulators. Curr Top Dev Biol 110: 189-216, 2014

11. Perk J, Iavarone A and BenezraR: Id family of helix-loop-helix proteins in cancer. Nat Rev Cancer 5: 603-614, 2005.

12. Wong YC, Wang X and Ling MT: Id-1 expression and cell survival. Apoptosis 9: 279-289, 2004

13. Shuno Y, Tsuno NH, Okaji Y, Tsuchiya T, Sakurai D, Nishikawa T, Yoshikawa N, Sasaki K, Hongo K, Tsurita G, et al: Id1/Id3 knockdown inhibits metastatic potential of pancreatic cancer. J Surg Res 161: 76-82, 2010.

14. Li B, Tsao SW, Li YY, Wang X, Ling MT, Wong YC, He QY and Cheung AL: Id-1 promotes tumorigenicity and metastasis of Human esophageal cancer cells through activation of PI3K/AKT signaling pathway. Int J Cancer 125: 2576-2585, 2009.

15. Maw MK, Fujimoto J and Tamaya T: Overexpression of inhibitor of DNA-binding (ID)-1 protein related to angiogenesis in tumor advancement of ovarian cancers. BMC Cancer 9: 430, 2009.

16. Lin J, Guan Z, Wang C, Feng L, Zheng Y, Caicedo E, Bearth E, Peng JR, Gaffney P and Ondrey FG: Inhibitor of differentiation 1 contributes to head and neck squamous cell carcinoma survival via the NF-kappaB/survivin and phosphoinositide 3-kinase/Akt signaling pathways. Clin Cancer Res 16: 77-87, 2010.

17. Liu Q, Zhang C, Yuan J, Fu J, Wu M, Su J, Wang X, Yuan X and Jiang W: PTK7 regulates Id1 expression in CD44-high glioma cells. Neuro Oncol 17: 505-515, 2015.

18. Fu J, Yang QY, Sai K, Chen FR, Pang JC, Ng HK, Kwan AL and Chen ZP: TGM2 inhibition attenuates ID1 expression in CD44-high glioma-initiating cells. Neuro Oncol 15: 1353-1365, 2013.

19. Clark PE, Spiess PE, Agarwal N, Biagioli MC, Eisenberger MA Greenberg RE, Herr HW, Inman BA, Kuban DA, Kuzel TM, et al Penile cancer: Clinical practice guidelines in oncology. J Natl Compr Canc Netw 11: 594-615. 2013.

20. Chen J, Yao K, Li Z, Deng C, Wang L, Yu X, Liang P, Xie Q, Chen P, Qin Z, et al: Establishment and characterization of a penile cancer cell line, penl1, with a deleterious TP53 mutation as a paradigm of HPV-negative penile carcinogenesis. Oncotarget 7: 51687-51698, 2016.

21. Jun F, Hong J, Liu Q, Guo Y, Liao Y, Huang J, Wen S and Shen L: Epithelial membrane protein 3 regulates TGF- $\beta$ signaling activation in CD44-high glioblastoma. Oncotarget 8: 14343-14358, 2017.

22. Wolff AC, Hammond ME, Schwartz JN, Hagerty KL, Allred DC, Cote RJ, Dowsett M, Fitzgibbons PL, Hanna WM, Langer A, et al: American Society of Clinical Oncology/College of American Pathologists guideline recommendations for Human epidermal growth factor receptor 2 testing in breast cancer. J Clin Oncol 25 : 118-145, 2007.

23. Faraj SF, Chaux A, Gonzalez-Roibon N, Munari E, Cubilla AL, Shih IeM and Netto GJ: Immunohistochemical expression of ARID1A in penile squamous cell carcinomas: A tissue microarray study of 112 cases. Hum Pathol 46: 761-766, 2015.

24. Yang Y, Huang JQ, Zhang X and Shen LF: MiR-129-2 functions as a tumor suppressor in glioma cells by targeting HMGB1 and is down-regulated by DNA methylation. Mol Cell Biochem 404 229-239, 2015

25. Li P, Tian W and Ma X: Alpha-mangostin inhibits intracellular fatty acid synthase and induces apoptosis in breast cancer cells. Mol Cancer 13: 138, 2014.

26. Zhang J, Fu J, Pan Y, Zhang X and Shen L: Silencing of miR-1247 by DNA methylation promoted non-small-cell lung cancer cell invasion and migration by effects of STMN1. Onco Targets Ther 9: 7297-7307, 2016.

27. Yang $\mathrm{C}, \mathrm{Xu} \mathrm{Y}$, Cheng $\mathrm{F}, \mathrm{Hu} \mathrm{Y}$, Yang $\mathrm{S}$, Rao J and Wang $\mathrm{X}$ : miR-1301 inhibits hepatocellular carcinoma cell migration, invasion, and angiogenesis by decreasing Wnt/ $\beta$-catenin signaling through targeting BCL9. Cell Death Dis 8: e2999, 2017.
28. He J, Xu Q, Wang M, Li C, Qian X, Shi Z, Liu LZ and Jiang BH Oral administration of apigenin inhibits metastasis through AKT/P70S6K1/MMP-9 pathway in orthotopic ovarian tumor model. Int J Mol Sci 13: 7271-7282, 2012.

29. Shan N, Shen L, Wang J, He D and Duan C: MiR-153 inhibits migration and invasion of Human non-small-cell lung cancer by targeting ADAM19. Biochem Biophys Res Commun 456: 385-391, 2015.

30. Zhang JF, Wang P, Yan YJ, Li Y, Guan MW, Yu JJ and Wang XD: IL-33 enhances glioma cell migration and invasion by upregulation of MMP2 and MMP9 via the ST2-NF- $\mathrm{BB}$ pathway. Oncol Rep 38: 2033-2042, 2017.

31. Hu X, Huang J, Wen S, Fu J and Chen M: Comparison of efficacy between brachytherapy and penectomy in patients with penile cancer: A meta-analysis. Oncotarget 8: 100469-100477, 2017.

32. Leone A, Diorio GJ, Pettaway C, Master V and Spiess PE: Contemporary management of patients with penile cancer and lymph node metastasis. Nat Rev Urol 14: 335-347, 2017.

33. Lopes A, Bezerra AL, Pinto CA, Serrano SV, de MellO CA and Villa LL: p53 as a new prognostic factor for lymph node metastasis in penile carcinoma: Analysis of 82 patients treated with amputation and bilateral lymphadenectomy. J Urol 168: 81-86, 2002.

34. Ferrandiz-Pulido C, Masferrer E, Toll A, Hernandez-Losa J, Mojal S, Pujol RM, Ramon y Cajal S, de Torres I and Garcia-Patos V: mTOR signaling pathway in penile squamous cell carcinoma: pmTOR and peIF4E over expression correlate with aggressive tumor behavior. J Urol 190: 2288-2295, 2013.

35. Poetsch M, Hemmerich M, Kakies C, Kleist B, Wolf E, vom Dorp F, Hakenberg OW and Protzel C: Alterations in the tumor suppressor gene $\mathrm{p} 16^{\mathrm{INK} 4 \mathrm{~A}}$ are associated with aggressive behavior of penile carcinomas. Virchows Arch 458: 221-229, 2011.

36. Cubilla AL: The role of pathologic prognostic factors in squamous cell carcinoma of the penis. World J Urol 27: 169-177, 2009.

37. Sanchez DF, Soares F, Alvarado-Cabrero I, Cañete S, Fernández-Nestosa MJ, Rodríguez IM, Barreto J and Cubilla AL: Pathological factors, behavior, and histological prognostic risk groups in subtypes of penile squamous cell carcinomas (SCC). Semin Diagn Pathol 32: 222-231, 2015.

38. Wang JY, Gao MZ, Yu DX, Xie DD, Wang Y, Bi LK, Zhang T and Ding DM: Histological subtype is a significant predictor for inguinal lymph node metastasis in patients with penile squamous cell carcinoma. Asian J Androl 20: 265-269, 2018.

39. Hu XM, Lin T, Huang XY, Gan RH, Zhao Y, Feng Y, Ding LC, Su BH, Zheng DL and Lu YG: ID1 contributes to cell growth invasion and migration in salivary adenoid cystic carcinoma. Mol Med Rep 16: 8907-8915, 2017.

40. Gupta GP, Perk J, Acharyya S, de Candia P, Mittal V, Todorova-Manova K, Gerald WL, Brogi E, Benezra R and Massagué J: $I D$ genes mediate tumor reinitiation during breast cancer lung metastasis. Proc Natl Acad Sci USA 104: 19506-19511, 2007.

41. Jacob JM, Ferry EK, Gay LM, Elvin JA, Vergilio J, Ramkissoon S, Severson E, Necchi A, Killian JK, Ali SM, et al: Comparative genomic profiling of refractory/metastatic penile and non-penile cutaneous squamous cell carcinoma: Implications for selection of systemic therapy. J Urol: Oct 3, 2018 (Epub ahead of print). pii: S0022-5347(18)43962-6. doi: 10.1016/j.juro.2018.09.056.

42. Marchi FA, Martins DC, Barros-Filho MC, Kuasne H, Busso Lopes AF, Brentani H, Trindade Filho JC, Guimarães GC, Faria EF, Scapulatempo-Neto C, et al: Multidimensional integrative analysis uncovers driver candidates and biomarkers in penile carcinoma. Sci Rep 7: 6707, 2017.

43. Ali SM, Pal SK, Wang K, Palma NA, Sanford E, Bailey M, He J, Elvin JA, Chmielecki J, Squillace R, et al: Comprehensive genomic profiling of advanced penile carcinoma suggests a high frequency of clinically relevant genomic alterations. Oncologist 21: 33-39, 2016.

44. McDaniel AS, Hovelson DH, Cani AK, Liu CJ, Zhai Y, Zhang Y, Weizer AZ, Mehra R, Feng FY, Alva AS, et al: Genomic profiling of penile squamous cell carcinoma reveals new opportunities for targeted therapy. Cancer Res 75: 5219-5227, 2015.

45. Chaux A, Munari E, Katz B, Sharma R, Lecksell K, Cubilla AL, Burnett AL and Netto GJ: The epidermal growth factor receptor is frequently overexpressed in penile squamous cell carcinomas: A tissue microarray and digital image analysis study of 112 cases. Hum Pathol 44: 2690-2695, 2013. 
46. Silva Amancio AM, Cunha IW, Neves JI, Quetz JD, Carraro DM Rocha RM, Zequi SC, Cubilla AL, da Fonseca FP, Lopes A, et al: Epidermal growth factor receptor as an adverse survival predictor in squamous cell carcinoma of the penis. Hum Pathol 61: 97-104, 2017.

47. Pillai S, Rizwani W, Li X, Rawal B, Nair S, Schell MJ, Bepler G, Haura E, Coppola D and Chellappan S: ID1 facilitates the growth and metastasis of non-small cell lung cancer in response to nicotinic acetylcholine receptor and epidermal growth factor receptor signaling. Mol Cell Biol 31: 3052-3067, 2011

48. Ding Y, Wang G, Ling MT, Wong YC, Li X, Na Y, Zhang X, Chua CW, Wang X and Xin D: Significance of Id-1 up-regulation and its association with EGFR in bladder cancer cell invasion. Int J Oncol 28: 847-854, 2006

49. Prowse DM, Ktori EN, Chandrasekaran D, Prapa A and Baithun S: Human papillomavirus-associated increase in p16 ${ }^{\mathrm{INK} 4 \mathrm{~A}}$ expression in penile lichen sclerosus and squamous cell carcinoma. Br J Dermatol 158: 261-265, 2008.
50. Adimonye A, Stankiewicz E, Kudahetti S, Trevisan G, Tinwell B, Corbishley C, Lu YJ, Watkin N and Berney D: Analysis of the PI3K-AKT-mTOR pathway in penile cancer: Evaluation of a therapeutically targetable pathway. Oncotarget 9: 16074-16086, 2018.

51. Lee TK, Man K, Ling MT, Wang XH, Wong YC, Lo CM, Poon RT, Ng IO and Fan ST: Over-expression of Id-1 induces cell proliferation in hepatocellular carcinoma through inactivation of $\mathrm{p} 16^{\text {INK4a }} / \mathrm{RB}$ pathway. Carcinogenesis 24: 1729-1736, 2003.

52. Alani RM, Young AZ and Shifflett CB: Id1 regulation of cellular senescence through transcriptional repression of p16/Ink4a. Proc Natl Acad Sci USA 98: 7812-7816, 2001

53. Lee JY, Kang MB, Jang SH, Qian T, Kim HJ, Kim CH, Kim Y and Kong G: Id-1 activates Akt-mediated Wnt signaling and p2 $7^{\text {Kipl }}$ phosphorylation through PTEN inhibition. Oncogene 28: 824-831, 2009. 